\title{
Hereditary persistence of fetal hemoglobin-beta-thalassemia syndrome
}

INSERM

\section{Source}

INSERM. (1999). Orphanet: an online rare disease and orphan drug data base. Hereditary persistence of fetal hemoglobin-beta-thalassemia syndrome. ORPHA:46532

Hereditary persistence of fetal hemoglobin (HPFH) associated with beta-thalassemia (see this term) is characterized by high hemoglobin ( $\mathrm{Hb}$ b) F levels and an increased number of fetal-Hb-containing-cells. 